\title{
Characterisation of the swimming muscles of two Subantarctic notothenioids*
}

\author{
DANIEL ALFREDO FERNÁNDEZ ${ }^{1}$, JORGE CALVO $^{1}$ and IAN ALISTAIR JOHNSTON² \\ ${ }^{1}$ CADIC-CONICET, (9410) Ushuaia, Tierra del Fuego, Argentina \\ ${ }^{2}$ Gatty Marine Laboratory, School of Environmental and Evolutionary Biology, University of St. Andrews, \\ St. Andrews, Fife KY16 8LB, Scotland
}

\begin{abstract}
SUMMARY: The histochemical characteristics and distribution of muscle fibre types have been investigated in the swimming muscles of the róbalo, Eleginops maclovinus and the lorcho, Patagonotothen tessellata, Subantarctic notothenioids that inhabit the Beagle Channel. The fibre types were differentiated on the basis of glycogen and lipid contents and succinate dehydrogenase and myofibrillar ATPase (mATPase) activities. White, red, intermediate and tonic fibres were present in the axial muscle of both species. The same fibre types were identified in the pectoral fin adductor muscles, although the intermediate type was absent. The mATPase technique performed at room temperature $\left(21^{\circ} \mathrm{C}\right)$ allowed a good differentiation of fibre types, overcoming the problems found by previous researchers when applying this technique to Antarctic notothenioids. Four different zones (peripheral, mosaic, main and adjacent to the bone) were found in the adductor profundis muscle. The proportion of the zones varied along the length of the adductor muscle. For both species, the percentage of red fibres found in the axial muscles was less than 5\%, indicating that sustained swimming ability is not dependent on these muscles. The pectoral muscle mass/carcase mass ratio was significantly greater in E. maclovinus than in P. tessellata, reflecting a greater capacity for sustained swimming using pectoral fins.
\end{abstract}

Key words: Subantarctic notothenioids, muscle histochemistry, swimming muscles, myosin ATPase.

RESUMEN: CARACTERIZACIÓN DE LOS MÚSCULOS DE LA NATACIÓN DE DOS NOTOTÉNIDOS SUBANTÁRTICOS. - Se investigaron la distribución y las características histoquímicas de los distintos tipos de fibras en los músculos responsables de la natación del róbalo, Eleginops maclovinus y del lorcho, Patagonotothen tessellata, nototénidos subantárticos que habitan las aguas del Canal del Beagle. En base a la distribución y morfología de las fibras y a la aplicación de técnicas histoquímicas se diferenciaron en la musculatura axial de ambas especies fibras blancas, rojas, intermedias y tónicas. En el músculo adductor profundis se encontraron los mismos tipos de fibras mencionadas exceptuando las fibras rosas. La técnica de mATPasa realizada a temperatura ambiente $\left(21^{\circ} \mathrm{C}\right)$ permitió diferenciar los distintos tipos de fibras, superando así las dificultades encontradas por otros autores al aplicar esta técnica en nototénidos antárticos. En la musculatura pectoral se diferenciaron 4 zonas: periférica, mosaico, principal y adyacente al hueso cuyas proporciones variaron a lo largo del músculo adductor. El porcentaje de fibras rojas encontrado en la musculatura axial de ambas especies fue bajo, menor al 5\%, lo que indica que la natación continuada no depende de la musculatura axial. En E. maclovinus el peso relativo de la musculatura pectoral con respecto al peso de la carcasa fue significativamente más alto que en $P$. tessellata. Esta diferencia refleja distintos grados de actividad de las aletas pectorales en la natación continuada de ambas especies.

Palabras clave: Nototénidos subantárticos, histoquímica de los músculos, músculos de natación, mATPasa.

*Accepted October 21, 1998. 


\section{INTRODUCTION}

Notothenioids are dominant in the Antarctic fish fauna comprising around 110 species grouped in six families (Ekau, 1991). This sub-order is highly endemic from Antarctic waters, with about $79 \%$ of species living south of the Antarctic Convergence (Eastman, 1993). It is thought they have evolved from a bottom-living ancestral stock of Perciformes around 20 million years ago, after the establishment of the circum-Antarctic currents (Johnston, 1993). Adults of most of the notothenioid species are demersal and sedentary, feeding and spawning on the bottom although larvae are pelagic. They lack a swim bladder and most of them are denser than seawater (Andriashev, 1965; Eastman, 1985; 1988; Eastman and De Vries, 1982; Fernández, 1997). Nevertheless some Antarctic species have special adaptations for pelagic life (Eastman, 1985; 1988; Eastman and De Vries, 1982). In this order, the family Nototheniidae is the one that shows the greatest diversity in length, body form, habitat and geographic distribution, with about 15 species living in Subantarctic waters (Eastman, 1993).

In Beagle Channel waters notothenioid fish are highly represented in the artisanal and scientific fisheries (López et al., 1997). Two of the most common species were investigated in the present study. They belong to the family Nototheniidae and differ in maximal final length, habitat and geographical distribution (Pequeño, 1981; Isla, 1993). Eleginops maclovinus Valenciennes, 1830 (róbalo), the only species of the genus Eleginopinae, has a very wide non-Antarctic distribution. This species reaches latitudes as far north as $35^{\circ}$ and $37^{\circ}$ $\mathrm{S}$ respectively, in both Atlantic and Pacific Oceans (Reagan, 1914; Norman, 1937; Andriashev, 1965). It is thought they separated early during the radiation of notothenioid fishes (Balushkin, 1990). Their present-day occurrence may reflect a historical distribution on part of the Gondwana shelf that did not become associated with the margins of the Antarctic plate (Eastman, 1993). Therefore, this species would have been relatively little influenced by large-scale tectonic movements or the subsequent cooling of the Southern Ocean during the Tertiary period (Johnston et al., 1998). E. maclovi$n u s$ is one of two euryhaline species of notothenioids inhabiting coastal waters. They also move into estuaries for spawning and feeding (Fischer, 1963 in Pequeño, 1981; Pequeño, 1981). The Bea- gle Channel population exhibits protandrous hermaphroditism (Calvo et al., 1992). Patagonothoten tessellata Richardson, 1845 (lorcho) is a small species that inhabits shallow waters and spawns in nests under the rocks in the intertidal zone in two spawning seasons (summer and winter). The males guard their nests and the fish show a pronounced sexual dimorphism (Rae and Calvo, 1989; 1995).

Histochemical techniques have been used to characterize muscle fibres in teleost fish from tropical, temperate and polar waters (Boddeke et al., 1959; Johnston et al., 1974; Hoyle et al., 1986; Mascarello et al., 1986; Brooks and Johnston, 1993). Four different fibre types have been found in many species: tonic (SDF, small diameter fibres), red, intermediate (pink) and white (Davison, 1983; te Kronnie et al., 1983; Mascarello et al., 1986; Gill et al., 1989; Higgins, 1990; Calvo and Johnston, 1992). However, several authors have also found subtypes (Asker and Osse, 1978; Carpene et al., 1982; Ramirez Zarzosa et al., 1991). Histochemical methods for myosin ATPase activity were not able to differentiate fibre types in Antarctic species (Davison and MacDonald, 1985; Harrison et al., 1987; Dunn et al., 1989). Davison and MacDonald (1985) found strong mATPase activity in pectoral muscles and weak one in axial muscle but in both cases, the staining was uniform, and it was not possible to differentiate muscle fibre types. Calvo et al., (1995) were the first to demonstrate the possibility of differentiating muscle fibre types in notothenioids working on larvae of $P$. tessellata using the mATPase histochemical technique.

Studies on Subantarctic notothenioids that live at higher temperatures than the Antarctic ones could be useful in distinguishing between phylogenetic and physical constraints due to low temperature (Johnston, 1989). In previous research, our group found that Subantarctic notothenioids showed higher mitochondrial respiration rates than the Antarctic ones even when the phylogenetic relationships between Subantarctic and Antarctic species were closer than inside the group of Subantarctic species studied (Johnston et al., 1998).

The aim of the present work was to study the swimming muscles of two Subantarctic notothenioid species with different locomotory habits, through the characterisation of the abundance and distribution of muscle fibre types continuing with comparative studies on Antarctic species that live at different temperatures. 


\section{MATERIAL AND METHODS}

\section{Sampling}

Fish were caught in the Beagle Channel near

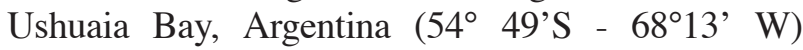
throughout 1994, 1995 and 1996 using trammel nets and traps. The surface water temperature ranged from $4{ }^{\circ} \mathrm{C}$ in winter to $10-11^{\circ} \mathrm{C}$ in summer. The body mass, carcase mass (body mass less gut, liver and ovaries), total length and sex (if identified) of the sampled fish were recorded. The adductor profundis muscle from one side of the fish was dissected and weighed.

\section{Histochemistry}

The distribution of muscle fibre types was studied in the trunk and the pectoral fin adductor profundis muscle. Axial muscles were sampled at 0.66 standard length (SL). The entire muscle was sectioned in the smaller fish $(<10 \mathrm{~cm})$ whereas several blocks were prepared in larger specimens $(>10 \mathrm{~cm})$. The whole pectoral muscles, including girdle bones, were sectioned when possible; if not, only the adductor profundis muscle was sampled. Muscle blocks were mounted on metal chucks and rapidly frozen in isopentane cooled to near its freezing point in liquid nitrogen $\left(-159^{\circ} \mathrm{C}\right)$. Blocks were equilibrated at $-20^{\circ} \mathrm{C}$ and $10 \mu \mathrm{m}$ frozen sections cut using a cryostat (Brights Instruments, Huntingdon, England).

Lipid and glycogen were stained using Sudan Black and the Periodic Acid Schiff's method respectively (Pearse, 1960). Sections were stained for succinic dehydrogenase activity (SDHase) in the dark following Nachlas et al. (1957). Sections were stained for myosin ATPase activity without and with preincubation at acid (30s to $5 \mathrm{~min}$; $\mathrm{pH} 4.3$ ) or alkaline $\mathrm{pH}$ (30s to $5 \mathrm{~min}$; $\mathrm{pH}$ 9.6, 10.2, 10.4 and 10.6) (Johnston et al., 1974).

\section{Cross-sectional area measurements}

Drawings of the area occupied for slow (red) and fast (white) muscles in the myotomes of both species were made in camera lucida. The drawings were scanned and subsequently analyzed using an image analysis software (Image Pro Plus for Windows).

\section{Statistics}

The differences in the adductor profundis weight /carcase mass proportion between species was tested using ANOVA.

\section{RESULTS}

The lateral superficial muscle (musculus rectus superficialis) in P. tessellata was composed of tonic, intermediate and red fibres and constituted around
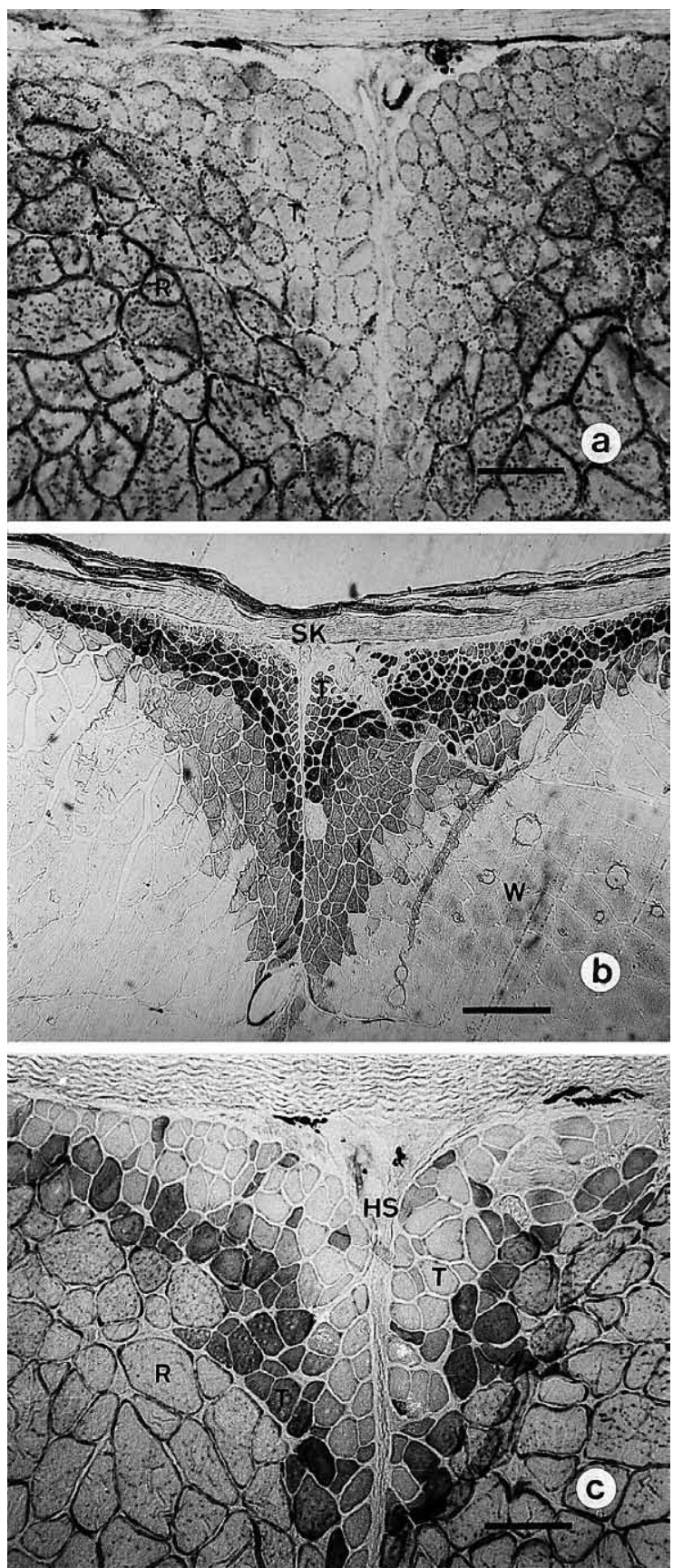

FIG. 1. - Histochemical staining characteristics of myotomal muscle fibre types in $P$. tessellata. Transverse frozen sections at the level of the horizontal septum (a) stained for succinic dehydrogenase activity (b) stained for mATPase following alkaline ( $\mathrm{pH} \mathrm{10,6;90s.)} \mathrm{preincu-}$ bation (c) stained for mATPase following acid ( $\mathrm{pH} \mathrm{4.3;90s.)} \mathrm{prein-}$ cubation, see differential activity in tonic fibres. $\mathrm{T}$ : tonic muscle fibres; R: red muscle fibres; I: intermediate muscle fibres; W: white muscle fibres; SK: skin; HS: horizontal septum, B: muscle bundles. Scale bar represents: $100 \mu \mathrm{m}$ (a) and (c); $400 \mu \mathrm{m}$ (b). 

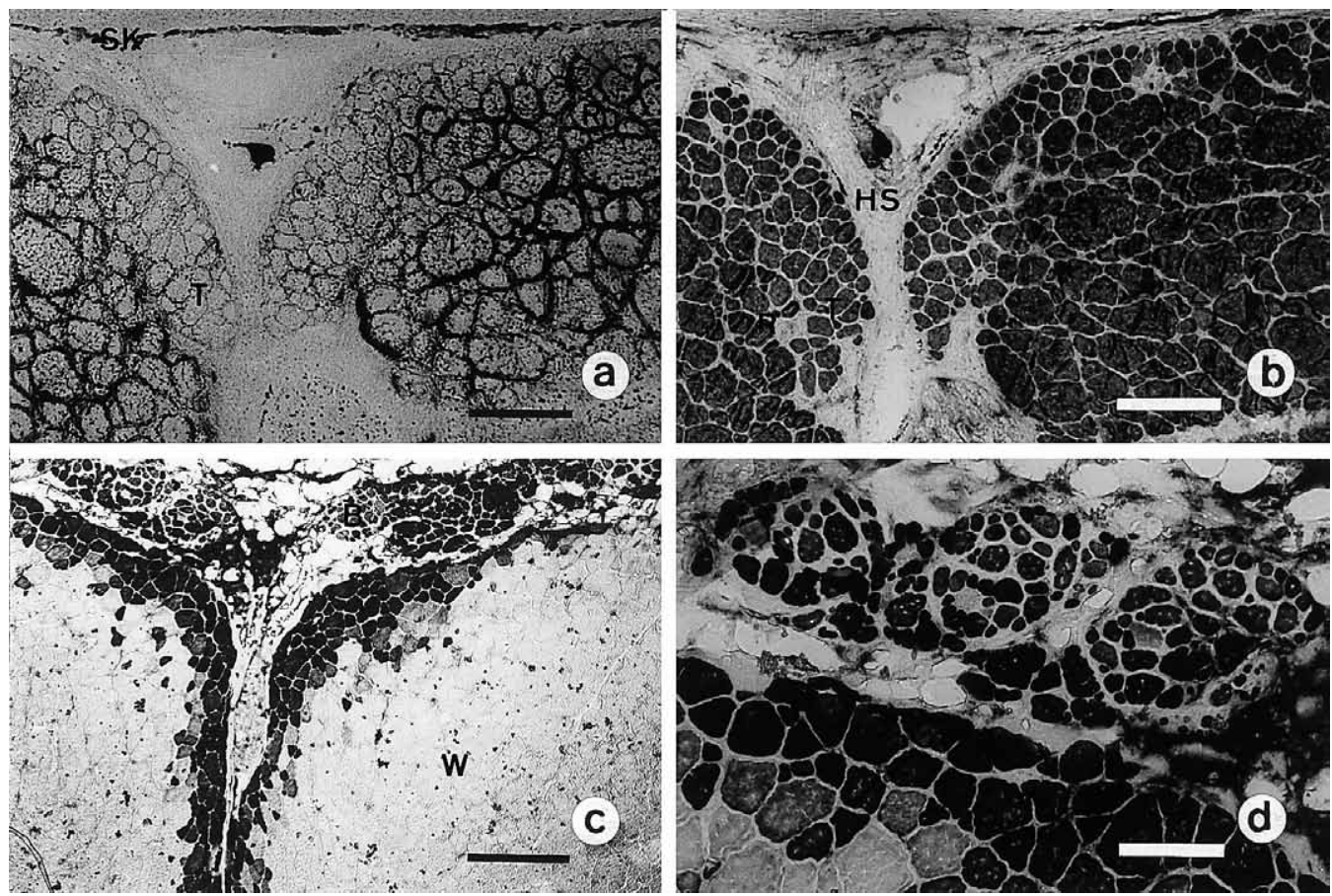

FIG. 2. - Histochemical staining characteristics of myotomal muscle fibre types in E. maclovinus. Transverse frozen section at the level of the horizontal septum (a) small E. maclovinus stained for mATPase following alkaline (pH 9.6; 30s.) preincubation (b) small E. maclovinus stained for succinic dehydrogenase activity (c) large E. maclovinus stained for mATPase activity following alkaline (pH 10,6; 90s.) preincubation, see the lateral muscle bundles (d) detail of the muscle bundles, stained for mATPase following alkaline (pH 10,6; 90 s.) preincubation, T: tonic muscle fibres; R: red muscle fibres; I: intermediate muscle fibres; W: white muscle fibres; SK: skin; HS: horizontal septum, B: muscle bundles. Scale bar represents: $100 \mu \mathrm{m}$ (a) and (b); $90 \mu \mathrm{m}$ (c) and $300 \mu \mathrm{m}$ (d).

$5 \%$ of the total cross-sectional area of the muscle. The central mass (musculus lateralis magnus) was composed of white fibres. One major and two minor thickenings could be distinguished in the superficial muscle. The major one was found at the level of the horizontal septum. The minor ones were located: one epiaxial, at the level of the dorsal lateral line, and the other one hypoaxial.

Four fibre types were differentiated using histochemical techniques. Tonic fibres were particularly abundant at the level of the horizontal septum and became less abundant dorsally and ventrally. They had small diameters and either did not stained or stain weakly for glycogen, lipid, succinic dehydrogenase (Fig. 1a) or myosin ATPase following alkaline preincubation (Fig. 1b). A proportion of the tonic fibres, mostly a population adjacent to the red muscle fibres, stained lightly for myosin ATPase following acid preincubation at $\mathrm{pH} 4.3$ (Fig. 1c). Red fibres were the most numerous fibres in the superficial muscle. They stained intensely for glycogen and lipid (not illustrated) and for succinic dehydrogenase (Fig. 1a). The myosin ATPase of the red fibres was the most resistant to inactivation following alkaline preincubation (Fig 1b). White muscle fibres comprised the bulk of the myotomal crosssection and stained lightly for glycogen, lipid and for succinic dehydrogenase (not illustrated). The myosin ATPase activity was slightly lighter than the one showed for red fibres without preincubation or following preincubation at $\mathrm{pH}$ 9.6. Nevertheless, following both acid and more alkaline preincubation $\mathrm{pH}$ (Fig. 1b) they were progressively inactivated. In the inner part of the superficial muscle, separated from the bulk of white fibres by connective fibres, there was a layer of intermediate or pink fibres. They stained lightly for myosin ATPase activity following alkaline preincubation (Fig. 1b) and intermediately for glycogen and succinic dehydrogenase.

The axial muscle of E. maclovinus showed a similar arrangement and histochemical staining characteristics of axial muscle fibre types to the $P$. tessellata, in spite of the fact that there were some differences. The lateral superficial muscle constituted about $3 \%$ of the total cross-sectional area of muscle. Tonic fibres were less abundant and only found at the horizontal septum. Intermediate fibres were few but very large, especially in small size animals (Fig. 2a,b). The lateral superficial muscle was no longer continuous but 


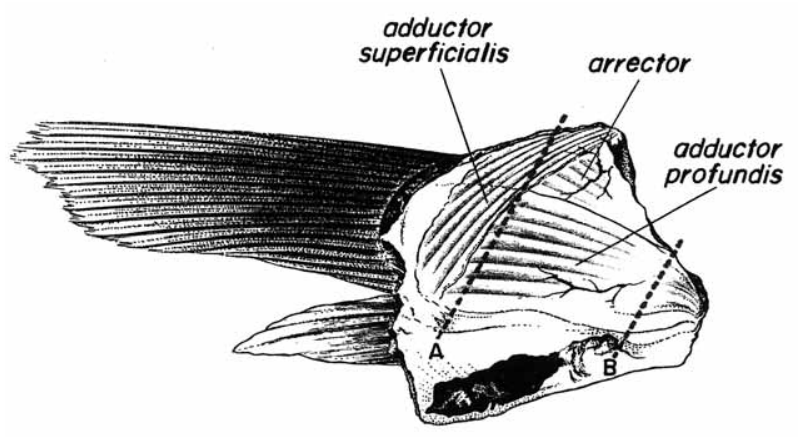

FIG. 3. - Pectoral fin muscle arrangement showing the places from where histochemical sections of the adductor profundis and superficialis muscles were taken (A) distal end (B) proximal end. in bundles (Fig. 2c) and there was an extensive layer of subcutaneous adipocytes surrounding each bundle (Fig. 2d), especially in animals larger than $25 \mathrm{~cm}$. Some fibres with red and intermediate characteristics could be seen inside the bulk of white fibres close to the horizontal septum following the mATPase staining with preincubation at $\mathrm{pH} 10.2$ or higher (Fig. 2c). White fibres were more resistant to alkaline preincubation than in $P$. tessellata, being completely inactivated at $\mathrm{pH}$ 10.6 (Fig. 2c).

A diagram of the morphology of the pectoral fin muscles is illustrated in Fig. 3 for E. maclovinus (a
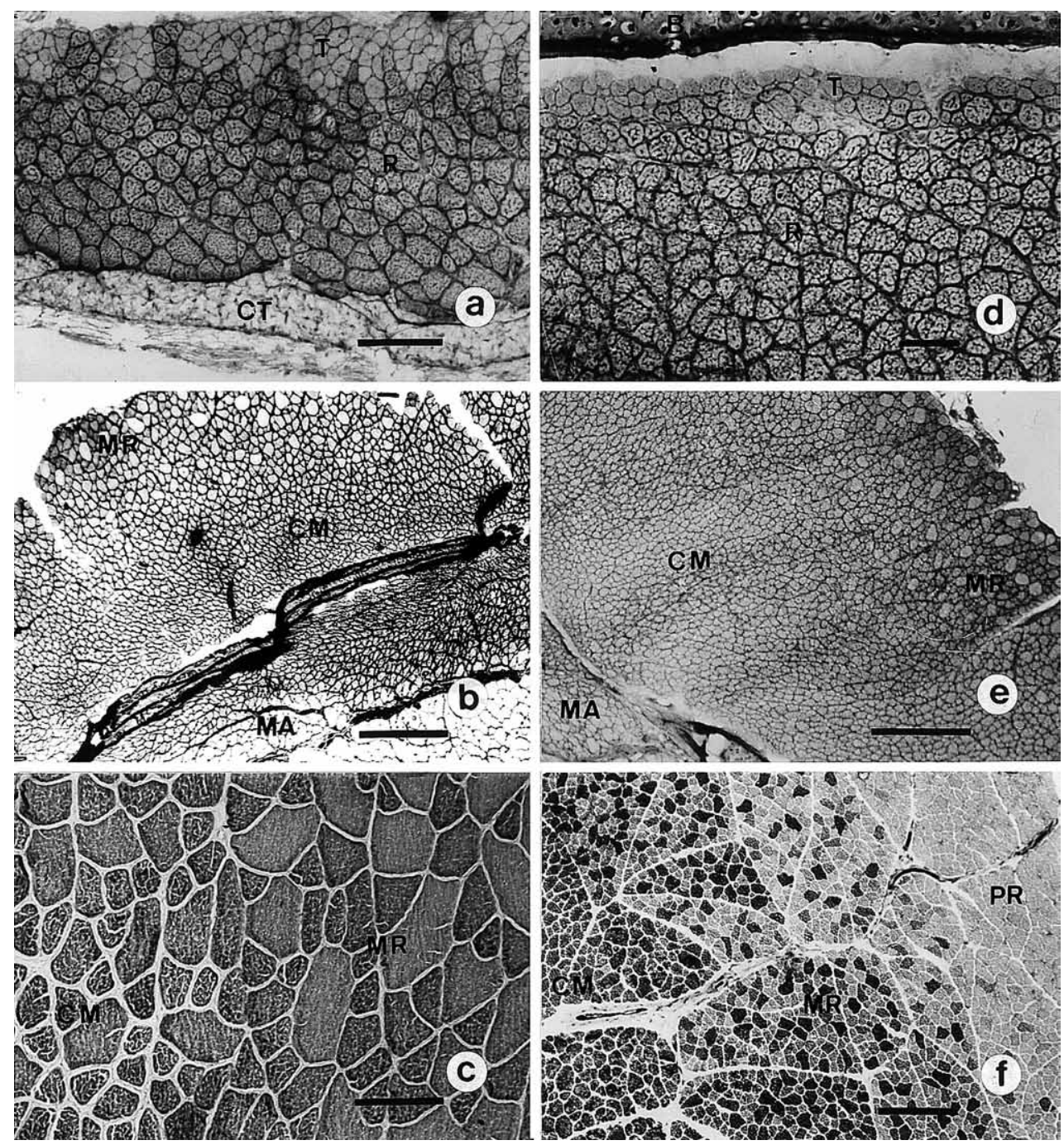

FIG. 4. - Histochemical staining characteristics of the pectoral fin adductor muscle of P. tessellata (a, b and c) and E. maclovinus (d, e and f): (a) section at the distal end of the muscle, stained for PAS-haematoxylin, note the tonic fibres adjacent to the girdle bones and the connective tissue that separates adductor profundis from adductor superficialis muscles; (b) section at the proximal end of the muscle stained for PAS-haematoxylin, see central mass and mosaic region; (c) central and mosaic regions stained for mATPase following alkaline (pH 10.6; 90s.) preincubation; (d) section at the distal end of the muscle, stained for succinic dehydrogenase activity, showing the narrow band of tonic fibres adjacent to the girdle bone; (e) section close to the proximal end of the adductor profundis muscle stained for glycogen (PAS-haematoxylin); and (f) large E. maclovinus adductor muscle section stained for mATPase following alkaline (pH 10.6; 90s.) preincubation. T: tonic muscle fibres; R: red muscle fibres; W: white muscle fibres; CM: central mass; MR: mosaic region; PR: peripheral region; MA: abductor muscle; B: bone; CT: connective tissue. Scale bar represents: $100 \mu \mathrm{m}$ (a), (c) and (d) and $400 \mu \mathrm{m}$ (b), (e) and (f). 
similar morphology could be seen in P. tessellata). Four zones could be distinguished in the adductor profundis muscle of both species: peripheral (white fibres), mosaic region (white and red fibres), main one (red fibres) and a distinct region adjacent to the bone (tonic and red fibres). Therefore, except for the absence of intermediate fibres, the same fibre types were present as described above for the myotome. The relative proportions of the different zones, however, varied from distal to proximal ends of the muscle (Fig. 3).

The peripheral zone was present at the proximal end of the muscle in the side opposite to the bone. It was composed of large diameter fibres that showed low mATPase and SDHase activity and small amounts of glycogen and lipids. The mosaic zone was placed in an inner part of the adductor muscle (Fig.4 b, c and e). There were large diameter white fibres with low activity surrounded by small red fibres with higher activity (mATPase, SDHase, glycogen and lipids). The main zone was composed of small diameter red fibres and represented the major part of the adductor muscle. These fibres stained intensely for glycogen (Fig. 4a) and succinic dehydrogenase (Fig. 4 d). A wide range of mATPase activity, showing a mosaic pattern, was observed after alkaline pre-incubation (Fig.4 f). Some large diameter fibres, similar to the intermediate ones found in the myotomal muscle of E. maclovinus, have been found in the adductor profundis muscle of the same species. The zone adjacent to the bone (mostly tonic fibres, with some red ones intermingled) was present only at the distal end of the muscle, as a narrow strip adjacent to the surface of the bone (Fig. 4 a, d). This zone was more extensive in P. tessellata that in E. maclovinus.

The ratio of adductor profundis muscle mass / carcase mass was significantly higher $(\mathrm{p}<0.01)$ in $E$. maclovinus $(0.010 \pm 0.0016)$ than in $P$. tessellata $(0.008 \pm 0.0016)$.

\section{DISCUSSION}

On the basis of differential inactivation of their mATPase at acid and alkaline preincubations muscle fibres containing different isoforms of myosin can be distinguished (Padykula, 1959; Johnston et al., 1974). SDHase activity is often used to classify fibres according to their aerobic capacity and also other histochemical techniques such as Periodic Acid Schiff (for glycogen) and Sudan Black (for lipids) are commonly used for fibre type characterisation. The utilisation of these histochemical techniques has been very useful for the characterisation of the different fibre types in the notothenioids species studied in this work. Four fibre types could be distinguished in axial muscle and three in pectoral muscle.

The mATPase activity results are in contrast with previous studies in notothenioids (Davison and Macdonald, 1985; Harrison et al., 1987; Dunn et al., 1989) in which it was not possible to differentiate between muscle fibre types using this technique at $4^{\circ} \mathrm{C}$. The reason for performing this technique at low temperature was the extremely high thermal lability reported for Antarctic fish myosine (Johnston et al., 1975; Perzanowska and Smialowska, 1981). It was also not possible to differentiate fibre types in the species studied in the present work when performing the technique at $4^{\circ} \mathrm{C}$. However, staining at room temperature resulted in good differentiation of fibre types following preincubation at different $\mathrm{pH}$.

The bulk of axial muscle in teleost fishes is composed of fast (white) fibres that utilise anaerobic metabolic pathways and are usually relatively resistant to alkaline preincubation when the mATPase stain is performed (Walesby and Johnston, 1980). Nevertheless, some species have shown different characteristics. Davidson (1983) found that white fibres of Gobiomorphus cotidianus were inactivated after preincubation at $\mathrm{pH} 10.2$ or higher while intermediate fibres were not inactivated. A similar mATPase activity of white fibres was found in the present study following alkaline preincubation but $P$. tessellata white fibres were inactivated at lower $\mathrm{pH}$ than E. maclovinus ones. Following similar treatments red fibres, that are readily inactivated by alkaline preincubation in temperate species (Johnston et al., 1974), showed strong activity in the present study for both species. These particular features of the Subantarctic notothenioids muscle fibres required further investigation in relation to their contraction speed. Contraction velocity and aerobic capacity are two properties of muscle that are important in determining swimming style and performance. Barany (1967) showed a positive correlation between biochemical measurements of myosin ATPase activity and the maximum speed of fibres shortening. Contraction speeds of Antarctic and Subantarctic notothenioid species have not been measured in relation to histochemical activity except for Johnston and Harrison (1985) who measured white and 
red fibres contractile properties taken from axial and pectoral muscles respectively. Therefore is not possible at present to discuss the validity of Barany's correlation in notothenioid fishes.

Three of the four zones found in the adductor profundis muscle of the Subantarctic notothenioids in the present study show correspondence with the ones found in other Antarctic notothenioid fishes (Walesby and Johnston, 1980; Davison and MacDonald, 1985; Dunn et al., 1989). These authors have not found the zone adjacent to the bone described in this study probably because this zone only appears if the section includes the bone and is made at the distal end of the muscle (fig. 4a and b). Davison and MacDonald (1985) found only red fibres in Pagothenia borchgrevinki but suggested that due to its pelagic life-style this species does not need white fibres to raise itself from the bottom or initiate forward movement as in most demersal notothenioids.

Three subtypes of red fibres have been found in pectoral muscle of E. maclovinus based on the mATPase activity. Despite these differences all the subtypes showed the same size and SDHase activity as well as similar glycogen and lipid contents. Therefore they were considered red fibres in the present study.

The small proportion of red muscle (slow muscle) found in the axial muscle of both species $(<5 \%)$ suggests that these fishes rely on labriform locomotion and have relative low maximum swimming speeds as found in other notothenioid fishes (Johnston and Harrison, 1985; Dunn et al., 1988). Swimming behaviour of both species in aquaria supports this suggestion. Both species seem to use subcarangiform locomotion for burst swimming and labriform locomotion for sustained swimming. The E. maclovinus is a more active swimmer holding its pectoral fins away from the body acting as hydroplanes to offset the downward thrust to the head (Fernández pers. obs.) as observed by Walesby and Johnston (1980) in Notothenia neglecta.

Structural adaptations observed in Antarctic notothenioids such as increased buoyancy (Eastman, 1993) allowed these fishes to occupy different habitats in Antarctic waters in the absence of competition (Eastman, 1985; 1988; Eastman and De Vries, 1982; 1986). It is likely that Subantarctic notothenioids have no special adaptations to increase buoyancy since all of them are demersal or semipelagic (Fernández, unpub. data). In the Magellan Region the competition could have been more intense due to the presence of other taxa which might have denied notothenioid fishes the possibility of having more pelagic lifestyles. It is important to make comparative studies on swimming behaviour and buoyancy of Antarctic and Subantarctic species in order to test this hypothesis.

\section{ACKNOWLEDGEMENTS}

The work was supported by an EU International Scientific Cooperation Grant on "Environmental influences on the ecology and physiology of Subantarctic fish", involving partners in Argentina, Italy and Scotland and P.I.A-CONICET $\mathrm{N}^{\circ}$ 6330/97. D.A.F. and J.C. were supported by CONICET. Authors are indebted to Mr. M. Barbagallo for the drawing.

\section{REFERENCES}

Andriashev, A.P. - 1965. A general review of the Antarctic fish fauna. In: P. van Oye and J. van Mieghem (eds.), Biogeography and Ecology in Antarctica, pp. 491-550. Monogr. Biol., XV, Junk, The Hague.

Asker, H.A. and J.W.M. Osse. - 1978. Muscle fibre types in the head of the perch Perca fluvialis (L), Teleostei. A histochemical and electromyographical study. Neth. J. Zool., 28: 94-110.

Balushkin, A.V. - 1990. Morphological basis of the systematics and phylogeny of the nototheniid fishes. Russian Translations Series 73 , A.A. Balkema, Rotterdam.

Barany, M. - 1967. ATPase activity of myosin correlated with speed of muscle shortening. J. gen. Physiol., 50: 197-216.

Boddeke, R., E.J Slijper and A. Van der Stelt. - 1959. Histological characteristics of the body musculature of fishes in connection with their mode of life. Proc. K. Ned. Akad. Wet., C, 62: 567588.

Brooks, S. and I.A. Johnston. - 1993. Influence of development and rearing temperature on the distribution, ultrastructure and myosin subunit composition of myotomal muscle-fibre types in the plaice Pleuronectes platessa. Mar. Biol., 117: 501-513.

Calvo, J. and I.A. Johnston. - 1992. Influence of rearing temperature on the distribution of muscle fibre types in the turbot Scophthalmus maximus at metamorphosis. J. Exp. Mar. Biol. Ecol., 161: 45-55.

Calvo, J., E. Morriconi, G.A. Rae and N.A. San Román. - 1992. Evidence of protandry in a subantarctic nototheniid, Eleginops maclovinus (Cuv. and Val., 1830) from the Beagle Channel, Argentina. J. Fish. Biol., 40: 157-164.

Carpene, E., A. Veggetti and F. Mascarello. - 1982. Histochemical fibre types in the lateral muscle of fishes in fresh, brackish and salt water. J. Fish. Biol., 20: 379-396.

Clarke, A. and I.A. Johnston. - 1996. Evolution and adaptive radiation of Antarctic fishes. TREE, 11 (5): 212 - 218.

Davison, W. - 1983. The lateral musculature of the common bully, Gobiomorphus cotidianus, a freshwater fish from New Zealand. J. Fish. Biol., 23: 143-151.

Davison, W. and J.A. MacDonald. - 1985. A histochemical study of the swimming musculature of Antarctic fish. New Zeal. J. Zool., 12: 473-483.

De Witt, H.H, P.C. Heemstra and O. Gon. - 1990. Nototheniidae. In: O. Gon and P. C. Heemstra (eds.), Fish of the Southern Ocean., pp. 279-331. J. L. B. Smith Institute of Ichthyology, Grahamstown, South Africa.

Dunn, J, .S.D. Archer and I.A. Johnston. - 1989. Muscle fibre types and metabolism in post-larval and adult stages of Notothenoid fish. Polar Biol., 9: 213-223.

Eastman, J.T. - 1993. Antarctic Fish Biology: Evolution in a Unique Environment. Academic Press, San Diego. 
Eastman, J.T. - 1985. The evolution of neutral buoyant Notothenioid fishes: their specialisation and potential interactions in the Antarctic marine food web. In: W. R. Siegfried, P.R. Condy and M.R. Laws (eds.), Antarctic Nutrient Cycles and Food Webs, pp. 430-436. Springer-Verlag, Berlin and Heidelberg.

Eastman, J.T. - 1988. Lipid storage system and the biology of two neutrally buoyant Antarctic Notothenioid fishes. Comp. Biochem. Physiol., 90B (3): 529-537.

Eastman, J.T. and A.L. De Vries. - 1982. Buoyancy studies of Notothenioid fishes in MacMurdo Sound, Antarctica. Copeia, 2: 385-393.

Eastman, J.T. and A.L. De Vries. - 1986. Antarctic fishes. Sci. Amer., 254 (11): 106-114.

Ekau, W. - 1991. Morphological adaptations and mode of life in high Antarctic fish. In: G. di Prisco, B. Maresca and B. Tota (eds.), Biology of Antarctic Fish, pp. 23-29. Springer-Verlag, Berlin.

Fernández, D.A. - 1997. Dinámica de crecimiento y caracterización histoquímica de las fibras musculares somáticas en Nototénidos subantárticos. Informe final de Beca de Iniciación de CONICET.

Gill, H.S., A H. Weatherley, R. Lee and D. Legere. - 1989. Histochemical characterization of myotomal muscle of five teleost species. J. Fish Biol., 34: 375-386.

Harrison, P., C.J.M. Nicol and I.A. Johnston. - 1987. Gross morphology, fibre composition and mechanical properties of pectoral fin muscles in the Antarctic teleost Notothenia neglecta (Nybelin). In: S.O. Kullander and B. Fernholm (eds.), Fifth Congress of European Ichthyologists, Proceedings, Stockholm 1985, pp. 459-465. Swedish Mus. Nat. Hist, Stockholm.

Higgins, P.J. - 1990. The histochemistry of muscle in juvenile Atlantic salmon, Salmo salar L. J. Fish. Biol., 37: 521-529.

Hoyle, J., H.S. Gill and A.H. Weatherley. - 1986. Histochemical characterization of myotomal muscle in the grass pickerel, Esox americanus vermiculatus (LeSeuer), and the muskellunge, $E$. masquinongy (Mithchell). J. Fish. Biol., 28: 393-401.

Isla, M.S. - 1993. Bioecología de Patagonotothen tessellata (Pisces, Nototheniidae) del Canal Beagle. Crecimiento y alimentación. Doctoral Thesis, Univ. Nacional de La Plata.

Johnston, I.A. - 1989. Antarctic fish muscles - structure, function and physiology. Antarct. Sci., 1 (2): 97-102.

Johnston, I.A. - 1993. Growth and metabolism in Antarctic fish. Antarct. Spec. Topic, 141-150.

Johnston, I.A. and G. Goldspink. - 1975. Thermodynamic activation parameters of fish myofibrillar ATPase enzyme and evolutionary adaptation to temperature. Nature, 257: 620-622.

Johnston, I.A. and P. Harrison. - 1985. Contractile and metabolic characteristics of muscle fibres from Antarctic fish. J. Exp. Biol., 116: 223-236.
Johnston I.A., S. Patterson, P. Ward and G. Goldspink. - 1974. The histochemical demonstration of myofibrillar adenosine triphosphatase activity in fish muscle. Can. J. Zool., 52: 871-877.

Johnston, I.A., J. Calvo, H. Guderley, D.A. Fernández and L. Palmer. - 1998. Latitudinal variation in the abundance and oxidative capacities of muscle mitochondria in Perciform fishes. J. Exp. Biol, 201: 1-12.

López, H.L., M.L. García and N.A. San Román. - 1996. Lista comentada de la ictiofauna del Canal Beagle, Tierra del Fuego, Argentina. Contrib. Cient. CADIC, 29: 1-85.

Mascarello, F., M.G. Romanello and P.A. Scapolo. - 1986. Histochemical and immunohistochemical profile of pink muscle fibres in some teleots. Histochem., 84: 251-255.

Norman, J.R. - 1937. Coast fishes, Part. II. The Patagonian Region. Disc. Rep., 16: 1-150.

Nachlas, M.M., K.C. Tsou, E. de Souza, C.S. Cheng and A.M. Seligman. - 1957. Cytochemical demonstration of succinic dehydrogenase by the use of a new p-nitrophenyl substituted dietrazole. J. Histochem. Cytochem., 5: 420-436.

Padykula, H.A. and E. Herman. - 1955. The specificity of the histochemical method for adenosine triphosphatase. J. Histochem. Cytochem., 3: 110-183.

Pearse, A.G.E. - 1960. Histochemistry, Theoretical and Applied. Second edition, Little Brown and Co., Boston.

Pequeño, G. - 1981. Peces de las riberas estuariales del río Lingue, Chile. Cah. Biol. Mar., 22: 141-163.

Pernazowska A. and E. Smialovska. - 1981. Electrophoretic study of the myofibrillar proteins from white and red blooded antarctic fish. Comp. Biochem. Physiol., 69(B): 79-83.

Rae, G. A. and J. Calvo. - 1989. Ciclo y hábitos reproductivos en Patagonotothen tessellata (Nototheniidae). XIV Reunión Argentina de Ecología, San Salvador de Jujuy.

Rae G.A. and J. Calvo. - 1995. Fecundity and reproductive habits in Patagonotothen tessellata (Richardson,1845) (Pisces, Nototheniidae) from the Beagle Channel, Argentine. Antarct. Sci., 7 (3): 235-240.

Ramirez Zarzosa, G., F. Gill, F. Moreno, J.M. Vazquez and R. Latorre. - 1991. Estudio histoquímico de las fibras musculares de algunos teleósteos marinos y de agua dulce. Anat. Histol. Embryol., 20: 169-179.

Reagan, C.T. - 1914. Fishes. Brit. Antarct. (Terra Nova) Exp. 1910, Nat. Hist. Rep., Zool., 1: 1-54.

te Kronie, G., L. Tatarczuch, W. van Raamsdonk and W. Kilarski. - 1983. Muscle fibre types in the myotome of the stickleback Gasterosteus aculeatus L.; a histochemical, inmunohistochemical and ultrastructural study. J. Fish Biol., 22: 303-316.

Walesby, N.J. and I.A. Johnston. - 1980. Fibre types in locomotory muscles of an antarctic teleost Notothenia rosii. Cell Tissue Res., 208: 143-164. 